\title{
Gamma Exposure Rates in the Steel Creek and Little Hell Landing Areas
}

by

R. Beul

Westinghouse Savannah River Company

Savannah River Site

Aiken, South Carolina 29808

DOE Contract No. DE-AC09-76SR00001

This paper was prepared in connection with work done under the above contract number with the U. S. Department of Energy. By acceptance of this paper, the publisher and/or recipient acknowledges the U.S. Government's right to retain a nonexclusive, royalty-free license in and to any copyright covering this paper, along with the right to reproduce and to authorize others to reproduce all or part of the copyrighted paper. 
This document was prepared in conjunction with work accomplished under Contract No. DE-AC09-96SR18500 with the U. S. Department of Energy.

\section{DISCLAIMER}

This report was prepared as an account of work sponsored by an agency of the United States Government. Neither the United States Government nor any agency thereof, nor any of their employees, makes any warranty, express or implied, or assumes any legal liability or responsibility for the accuracy, completeness, or usefulness of any information, apparatus, product or process disclosed, or represents that its use would not infringe privately owned rights. Reference herein to any specific commercial product, process or service by trade name, trademark, manufacturer, or otherwise does not necessarily constitute or imply its endorsement, recommendation, or favoring by the United States Government or any agency thereof. The views and opinions of authors expressed herein do not necessarily state or reflect those of the United States Government or any agency thereof.

This report has been reproduced directly from the best available copy.

Available for sale to the public, in paper, from: U.S. Department of Commerce, National Technical Information Service, 5285 Port Royal Road, Springfield, VA 22161, phone: (800) 553-6847, fax: (703) 605-6900

email: orders@ntis.fedworld.gov

online ordering: http://www.ntis.gov/ordering.htm

Available electronically at http://www.doe.gov/bridge

Available for a processing fee to U.S. Department of Energy and its contractors, in paper, from: U.S. Department of Energy, Office of Scientific and Technical Information, P.O. Box 62, Oak Ridge, TN 37831-0062,

phone: (865)576-8401,

fax: (865)576-5728

email: reports@adonis.osti.gov 


\section{DISCLAIMER}

Portions of this document may be illegible in electronic image products. Images are produced from the best available original document. 
TECHNICAL DIVISION

SAVANNAH RIVER LABORATORY

January 20, 1975

DISTRIBUTION FOR DPST-74-55I (REVISED), "GAMMA EXPOSURE RATES IN THE STEEL CREEK AND IITTLE HELL IANDING AREAS":

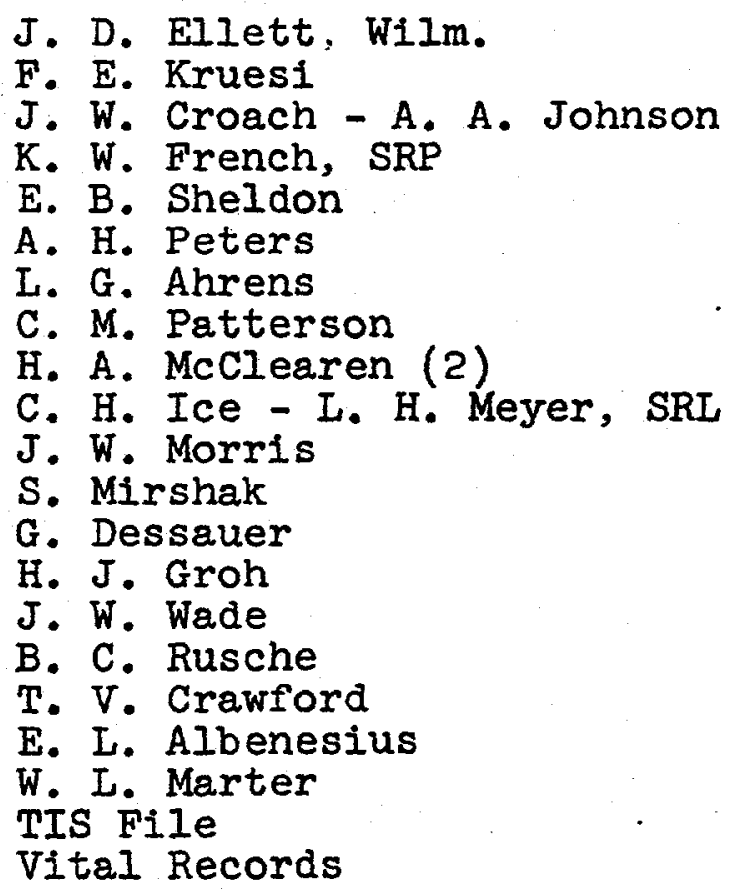

Please remove your file copy of DPST-74-551, dated December 13, 1974 , and replace with the attached revision, dated January $20,1975$. 
DPST-74-551

REVISED

TECHNICAL DIVISION

SAVANNAH RIVER LABORATORY

GAMMA EYPOSURE RATES

IN THE

STEEL CREEK AND LITTLE HELL LANDING AREAS

BY

W. I. MARTER

January 20, 1975 


\section{SUMMARY}

Aeroradiographic and ground transect surveys in the summer of 1974 were conducted to determine the degree of offsite contamination in an area immediately below the Savannah River plant boundary. The results of these studies were published in report DP-1370, "Radioactivity From SRP Operations in a Downstream Savannah River Swamp: by W. L. Marter

It is recognized that mechanisms in the biosphere tend to cause nonhomogenous distribution and redistribution of radionuclides released to the environment. To define these redistribution patterns as much as is practicable, a plan was developed to continualiy evaluate the offsite area. As part of this plan, a 1300-foot-long section of offsite swamp ( 42.9 acres) adjacent to the SRP boundary was surveyed in the latter half of October 1974 on a 10-foot grid pattern: The results of this survey show that 6.6 of the 42.9 acres surveyed in detail had exposure rates exceeding $57 \mu \mathrm{R} / \mathrm{hr}(-500 \mathrm{mR} / \mathrm{yr})$. The maximum exposure rate found at a single grid point was $120 \mu \mathrm{R} / \mathrm{hr}$. Approximately $5.8 \mathrm{Cl}$ of cesium-137 is deposited in the 42.9-acre 10-foot grid survey area.

A hypothetical person (none exists) residing continuously in the location of highest exposure rate when the swamp is not flooded (77\% of the time each year) could recelve an annual dose of about $809 \mathrm{mR}$. Previous surveys of this area indicated a maximum external annual dose of $357 \mathrm{mR}$ under the same residency conditions. Even with the higher exposure rates detected in the 10-foot grid survey, the more probable incremental radiation dose (above background) to hunters and fishermen who spend $a$ few hours to $a$ few hundred hours in this section of swamp would range from 1 ess than $1 \mathrm{mR}$ to a few tens of $\mathrm{mR}$ per year.

PREVIOUS SWAMP SURVEYS

During the 1960's, approximately $25 \mathrm{Cl}$ of cesium-137 ( $\left.{ }^{137} \mathrm{Cs}\right)$ and less than $1 \mathrm{Cl}$ of cobelt-60 ( $60_{\mathrm{Co}}$ ) were deposited in a downstream Savannah River swamp(I), primarily as a result of releases of radioactivity from $P$ and $L$ reactor fuel storage basins to Steel Creek. The radioactivity in the swamp, mostly associated with sediments, was deposited during periods of swam flooding which occurs an average 23 percent of the time each year. Aeroradiographic and ground transect surveys made in June 1974 and July-August 1974 , respectively, revealed net gamma exposure rates (three feet above the ground) of $53 \mathrm{\mu R} / \mathrm{hr}(464 \mathrm{mr} / \mathrm{yr})$ maximum except for an exposure rate of $67 \mu \mathrm{R} / \mathrm{hr}$ (590 mR/yr) on a small strip of land, several yards wide, between two sloughs containing standing water. This area was located in a swamp transect at River Mile 138.5, about one mile northwest of Little Hell Landing.

The swamp between the SRP boundary at Steel Creek and the SRP boundary at Lower Three Runs Creek is approximately five square miles in area. The area of the swamp containing radiation levels above natural background is 1.9 square miles (1235 acres). About 93 percent of the radioactivity is in the 3.5-mile-iong section of swamp between the SRP boundary (at Steel Creek) and Iittle Hell Landing and about 20 percent is in a $1300-$ foot-long section (61.7 acres) just east of the SRP boundary at Steel Creek. 
A Barnwell County road (SC 493) and a boat launching ramp at the river, called Steel Creek Landing Road and Steel Creek Landing, respectively, are located in the 1300-foot long section of swamp adjacent to the SRP boundary near steel Creek. As part of the program to evaluate radioactivity in the swamp, investigating surveys were conducted to gather information to guide future work. These surveys confirmed the need for a detalled ground survey of the swamp area where the aerial survey had indicated the spots of highest concentration of radioactivity should exist. A ground survey team was assigned to make a comprehensive survey of this section of swamp on a 10-foot grid pattern. The Iocation of the grid survey is shown in Figure 1, an aerial photograph of the general area encompasing steel Creek Landing.

The grid pattern for the radiation survey was lald out by a mapping team from the SRP Project Department. Wooden stakes were used to mark grid points at 100-foot intervals on a north-south ine at the SRP boundary. This western-most IIne was designated by the letter " $A$ " and 100-foot intervals along the line were Identified with numbers, arbitrarily starting w1th "30" at the north end and increasing consecutively in a southerly direction. Similar grid ines were laid out east of and parallel to line $A$ at 100 -poot intervals and were assigned letter designations "B" through "P" ("I" and "O" omitted).

The radiation survey of the swamp was made in a series of "sweeps" through the swamp in a north-south direction by a team of 10 surveyors and a data recorder. The surveyors were each equipped with portable gamma scintillometers (Technical Associates, Model Fs-1I) which had been calibrated with a radium source. The surveyors formed an eastwest IIne 10 feet apart and walked southward, stopping every 10 feet to make an exposure rate measurement and to record data. Thus, for each major 100-foot grid marked by wooden stakes, 100 exposure rate readings were recorded on a 10-fcot grid. In order to expedite the overall survey, survey data were recorded only in those areas where general gross gamma exposure rates exceeded $30 \mu \mathrm{R} / \mathrm{hr}$. Approximately 19,000 measurements were recorded over a two-week period. The recorded data represented gross gamma exposure rates in reference to instrument response to a radium-226 calibration source and were ur.corrected for natural background exposure rate. The large number of field measurements were coded and computer stored to facilitate correction, analys1s, and mapping.

*This aerial photograph was taken on April 6, 1973 when the swamp was flooded during a:-perlod of high river flow ( 95.8 feet MSL a: SRP boat dock). The river:elevatior at steel Creek Landing was atout 86 feet above mean sea level (MSI) at the itime the photograpr was taken. Water extends almost to the edge of the swamp margin and covers most of the unpaved erid of the Steel Creek Landing Rcad t; an elevation of about 86 feet MSL. 
GROSS GAMMA ADJUSTMENT

The portable gamm scintillometers were calibrated to give uniform radiation response with a radium-226 source prior to the 10-foot $\mathrm{grid}$ swamp survey. The response of the NaI(TI) detector 18 energy dependent with maximum response to gamma energy of about $0.3 \mathrm{MeV}$ and decreasing In response as gamma energy increases. Cesium-137 emits a gamma photon with an energy of about $0.66 \mathrm{MeV}$; radium-226 in equilibrium with its daughters emits an effective mean gamme energy of about $0.78 \mathrm{MeV}$ but $1 \mathrm{~s}$ made up of a large number of discrete gamma energies ranging from 0.05 to $1.76 \mathrm{MeV}$. Scintillometers calibrated with radium will overrespond to the lower energy from cesium-137. To correct for this, radium calibrated thermoluminescent dosimeters (energy independent in response to a wide range of gamma radiation energies) were exposed for perlods of five to seven days at three feet above the ground at each of the major 100-foot grid points in the swamp. The exposure rates at each grid point, as determined by TLD's, were plotted versus scintillometer readings at the same point. With these data, a formula for a least-squares fit line of regression was derived, including correction for natural background exposure rate. The equation was

$$
\begin{aligned}
& \text { Net Exposure Rate }=0.83 X-8.95 \\
& \text { Where: } X=\text { scintillometer reading, } \mu R / h r
\end{aligned}
$$

Twelve different scintillometers were used during the survey. Accuracy of survey data were determined by measuring known exposure rates from a cesium-137 source with six of the instruments used in the survey. The deviation of gamma exposure rate response between survey instruments increases as exposure rate increases as shown in. Table 1 .

\section{Table 1}

Exposure Rate, $\mu R / h r$

$$
\begin{array}{r}
26.3 \\
44.0 \\
73.1 \\
90.3 \\
100.3 \\
126.3 \\
153.8
\end{array}
$$

Standard Deviation $(1 \sigma), \%$

4.6

7.6

7.6

8.7

13.7

14.5

15.6 
EFFECT OF SOIL MOISTURE CONTENT

The 10-foot grid survey of the swamp was made in the latter half of October 1974. The swamp was unusually dry because only 0.08 inch of rain fell during, the entire month, none during the survey. The average ralnfali in October at SRP (21 years of record) is 2.57 inches and only in two previous months (both in october) out of 252 (21 years) has the rainfall been less.

\section{Table 2}

\section{Average Precipitation at SRP}

Month

January

February

March

Apr11

May

June

July

August

September

October

November

December

Total
Average Rainfall, in.

\begin{tabular}{l}
4.1 \\
4.3 \\
5.1 \\
3.5 \\
3.8 \\
4.5 \\
4.8 \\
4.7 \\
3.8 \\
2.6 \\
2.2 \\
3.6 \\
\hline 47
\end{tabular}

The effect of soll molsture on gamma exposure rates was determined by measurements in the swamp with TLD's, scintillometers, and lonization chambers before and after a rainfall early in November 1974. The shielding effect of water in saturated swamp soll reduced exposure rates approximately 10 percent. This was verified by laboratory tests. From the past history of rainfall, it appears unlikely that exposure rates measured in the october 1974 grid survey will ever be exceeded as a result of soll dryness. The survey data presented in the following section therefore represents the upper limit of exposure rates under present depth distribution (geometry) of the cesium deposits.

METHOD OF PRESENTING SURVEY DATA

The grid spacing used in the swamp survey was selected because FS-1I gamma scintillometer detectors have a circle of resolution of approximately 10 feet in diameter when measuring three feet above a plane source, 1 .e., an area of about 79 square feet. Each instrument reading, however, was taken to represent a 10-foot grid (100 ft2) to simpilfy the survey. 
METHOD OF PRESENTING SURVEY DATA (CONTINUED)

Figure 2 is a map of the 10-foot grid survey area. The east-west scale is about 20 percent greater than the north-south scale in order to make the map compatible with computer printout sheets used in following figures. ThIs map shows the SRP boundary, Steel Creek Landing Road (with elevations above mean sea level), Steel Creek Landing, the edge of the Savannah River, and the major 100-foot grid scale. This map, with computer printout overlays, is used to present results of the 10-foot grid survey.

THE SURVEY DATA

Figure 3 shows the computer printout of net gamma exposure rates in $5 \mathrm{\mu R} / \mathrm{hr}$ increments at 18,696 points on the 10-foot grid survey area. The highest net exposure rate found was $120 \mu \mathrm{R} / \mathrm{hr}$. Data from Flgure 3 are summarized in the Appendix.

The areas in Figure 3 designated with the large letters "A" and "B", 4.1 and 2.9 acres, respectively, were reconnoltered and no gross exposure rates greater than $30 \mu \mathrm{R} / \mathrm{hr}$ (net exposure rate of $16 \mu R / \mathrm{hr}$ ) were found; these areas were not surveyed on a 10-foot grid. The area designated " $C$ " (11.5 acres) was impenetrable because of boggy conditions; however, a few survey readings in the edges of this area, along with data from the EG\&G aeroradiographic survey of June 1974 lead to the conclusion that very little radioactivity is deposited in this area.

Figure 4 shows the same data as Figure 3 except exposure rates are shown in $20 \mu \mathrm{R} / \mathrm{hr}$ increments. Areas that could not be surveyed because of water $(0.3$ acre) are shown by equal $(=)$ signs. On the right side of this figure, the path of Boggy Gut Creek is clearly evident.

Figure 5 shows all survey points where exposure rates exceed $57 \mu \mathrm{R} / \mathrm{hr}$ ( $2500 \mathrm{mR} / \mathrm{yr}$ ). This represents about 6.6 acres and is located in an area bordering the swamp margin which is generally depressed in elevation ( $a$ swale). If it is assumed that a person could reside in the swamp $77 \%$ of the time (flooded $23 \%$ of the time) (1), an exposure rate of $74 \mu \mathrm{R} / \mathrm{hr}$ would cause an annual dose of $500 \mathrm{mR}$. Flgure 6 shows grid polnts where exposure rates exceed $74 \mathrm{\mu R} / \mathrm{hr}$. From Figure 6 it was determined that 110 grid points (0.25 acre) showed exposure rates that exceed $74 \mathrm{\mu R} / \mathrm{hr}$.

Figures 7 through 12 are single character computer printouts showing net gamma exposure rates in $20 \mu \mathrm{R} / \mathrm{hr}$ increments (Table 3 ). 
THE SURVEY DATA (CONTINUED)

\section{Table 3}

Flgure Number

7
8
9
10
11
12
Exposure Rate Range, $\mu \mathrm{R} / \mathrm{hr}$

$$
\begin{gathered}
0-20 \\
20-40 \\
40-60 \\
60-80 \\
80-100 \\
100-120
\end{gathered}
$$

\section{AMOUNT OF RADIOACTIVITY DEPOSITED}

Previous swamp ground transect surveys in July-August 1974(I) established a relationshlp between gross gamma exposure rates and measured radioactivity in swamp sediments. From this relationship, the amount of cesium-137 deposited in the 1300-foot-long section of swem borderling the SRP boundary near Steel Creek was calculated. The results of these calculations are shown in Table 5 .

\section{Table 5}

\section{Radioactivity Deposited In Swamp}

Iocation

Wilas than $500 \mathrm{mR} / \mathrm{yr}$ (100\% occupancy)

- Grid Area

- Area "A" Area "B" $\begin{aligned} & \text { Figure } 3 \\ & \text { - Area "C" } \\ & \text { - Creeks }\end{aligned}$

Subtotal

Greater than $500 \mathrm{mR} / \mathrm{yr}$ (100\% occupancy)

- Grid Area

Grand Total
Acres Curies

36.4

4.1

2.9

11.5

0.3

55.2

$5.5 \max$

6.6

1.4

61.8

$6.9 \max$

*An upper limit based on an assumed uniform gross gamma exposure rate
of $30 \mu \mathrm{h} / \mathrm{hr}$.

The 1300-foot-long section of swamp bordering the SRP boundary is estimated to contain $6.9 \mathrm{Cl}$ of cesium-137 based on the 10-foot grid survey. It was estimated that this section of swamp contains about $5 \mathrm{Cl}$ of cesium-137 based on exposure rates measured in the June 1974 aeroradiographic survey. The $5 \mathrm{Cl}$ estimated from the aeroradiographic survey is in fair agreement with the $6.9 \mathrm{Cl}$ calculated from the 10-foot grid survey considering the nonhomogeneity of radioactivity deposition, the relatively small number of ground transect survey readings in this area in the July-August 1974 survey, and the broader areal resolution of the aeroradiographic survey. 


\section{LITTLE HELL LANDING SURVEY}

On November 12,1974 , a reconnaissance survey was made (with portable scintillometers) of the swamp area between Ifttle Hell Landing and River Mile 135.3 (Reference 1, Figure 12) to the west of the landing. The survey area ranged in width from about 1200 feet along the swamp margin to about 300 feet wide near the river. Highest exposure rates were detected in a swale bordering the swamp margin. In this swale, maximum net gamma exposure rates of about $35 \mu \mathrm{R} / \mathrm{hr}$ (corrected) were detected at two locations. All other net exposure rates in the swale were less than $30 \mu \mathrm{R} / \mathrm{hr}$. This indicates that the cesium-137 deposition at this location is less concentrated and is more homogenously distributed than in the grid survey area adjacent to the SRP boundary.

\section{CONCLUSIONS}

A 10-foot grid ground survey of a 1300-foot-liong section of the Savannah River Swamp below the SRP boundary near Steel Creek detected nonhomogeneities of radioactivity deposition not detected in the July-August 1974 ground transect survey and the June 1974 aeroradiographic survey. In scattered locations, representing about 0.25 acre of swamp, a hypothetical swamp resident who lived in the swamp for 77 percent of the time when the swamp is not flooded could recelve gamma doses of 500 to $809 \mathrm{mR} /$ year. Previous surveys indicated a maximum external gamma dose of $357 \mathrm{mR} / \mathrm{yr}$ under the same residency conditions. Residency in the swamp is unlikely. The more probable incremental radiation dose (above background) to hunters and fishermen who spend a few hours to several hundred hours in this section of swamp would range from less than $I \cdot m R$ to a few tens of $m R$ per year.

Nonhomogenous radioactivity deposition likely occurs in the offsite swamp east of the area surveyed on a 10-foot grid pattern. However, the June 1974 aeroradiographic survey (Ref. 1, Flgure 15) indicates that the cesium-137 deposition per unit aree in other sections of the swamp is lower than in the grid-surveyed area; thus, the grid-survey area probably represents the location of highest gamma exposure rates.

A reconnalssance survey near Little Hell Landing in November 1974 lends support to this conclusion.

\section{ACKNOWLEDG EMENTS}

Mapping and layout of the grid survey area was performed by the SRP Project Department. Radiation surveys in the swamp were made by the SRP Health Physics Section. Computer programming for analysis and mapping of survey data was by $R$. E. Cooper of Environmental Analysis and Planning.

\section{REFERENCES}

1. W. I. Marter, "Radioactivity from SRP Operations in a Downstream Savannah River Swamp,"DP-1370, September 1974. 
APPENDIX

SURVEY DATA FROM FIGURE 3

\section{Exposure Rate} $\mu \mathrm{R} / \mathrm{hr}$

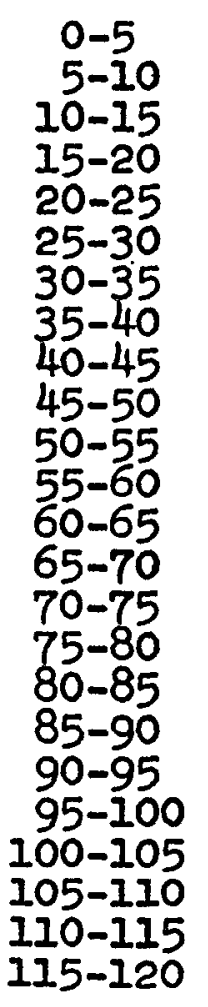

TOTAL

Background

Water

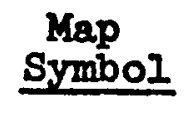

0

1

2

3

5

7

9

A

B

C

D

$\mathrm{F}$

G

H

$\mathrm{J}$

$\mathrm{K}$

M

N

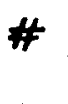

$=$
Number of

Grid Points

254

288

288

746

2286

1362

1514

1357

3603

2269

1867

1381

673

579

17

25

-1:.

49

0

2

$\pm$

18,696

3

134
Acres

0.5831

0.6612

0.6612

1.7126

5.2479

3.1267

3.4757

3.1152

8.2713

5.2089

4.2860

3.1703

1.5450

1.3292

0.2663

0.0390

0.0482

0.0253

0.1125

0.0184

0.0046

0.0023

0.0023

42.9

0.0069

0.3076
Curies

$137 \mathrm{Cs}$

0.0083

0.0187

0.0281

0.0970

0.3726

0.3105

0.3936

0.3976

1.1710

0.8123

0.7897

0.6284

0.3284

0.3011

0.0679

0.0105

0.0137

0.0075

0.0350

0.0062

$0 . \overline{0017}$

0.0009

0.0009

5.8 


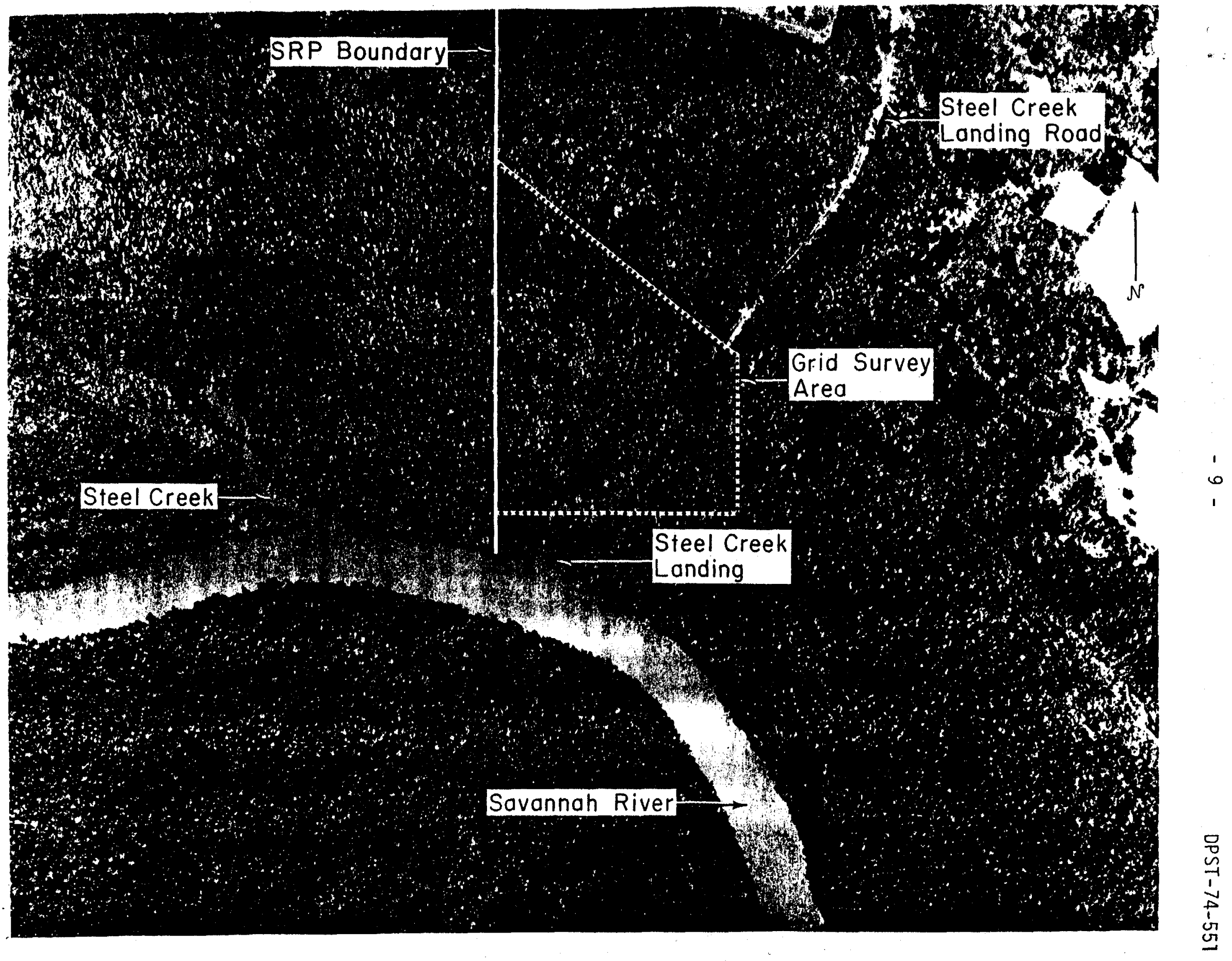

FIGURE 1. Aerial Photograph of Grid Survey Area 


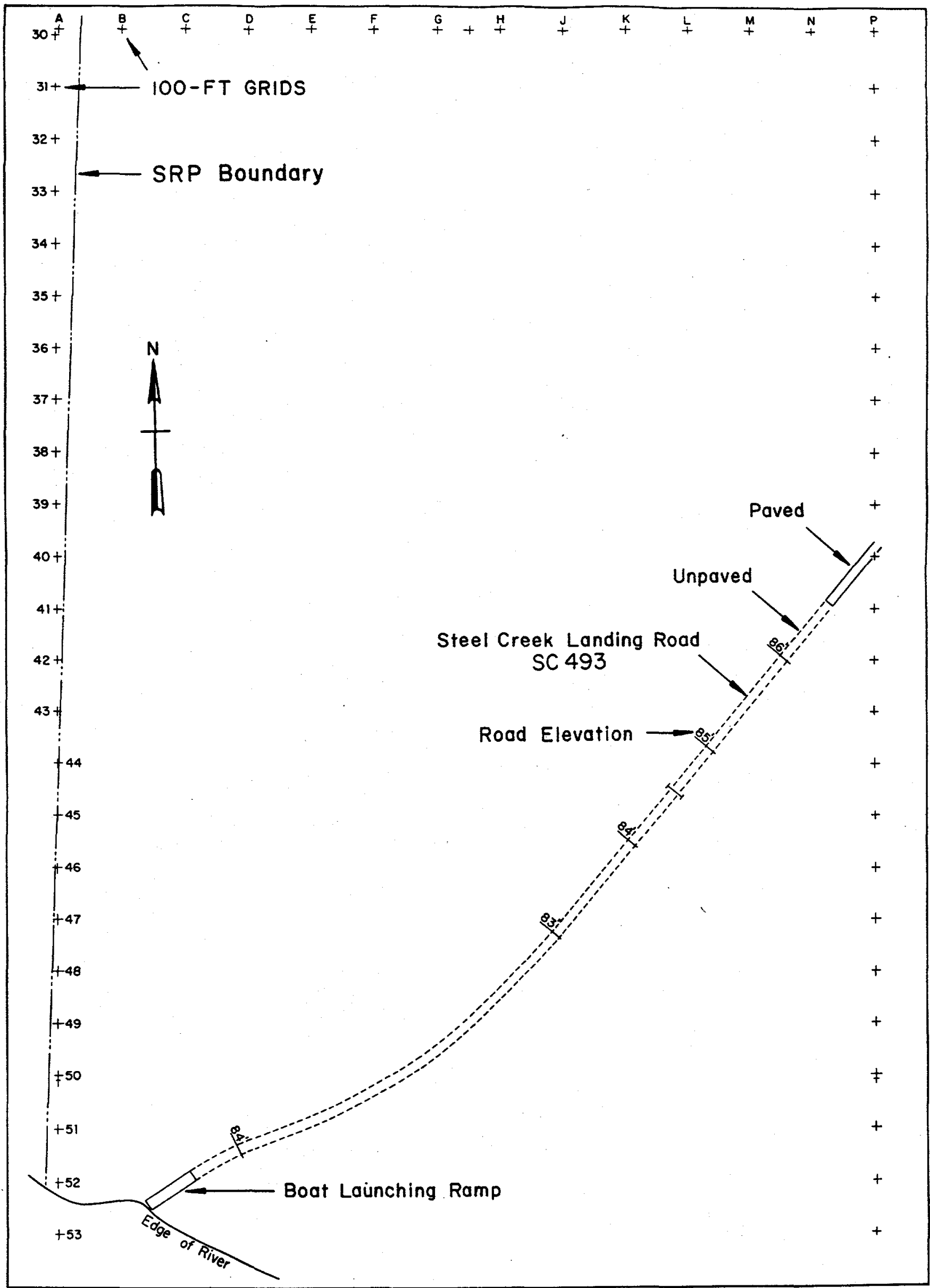

FIGURE 2. Master Grid Survey Map 


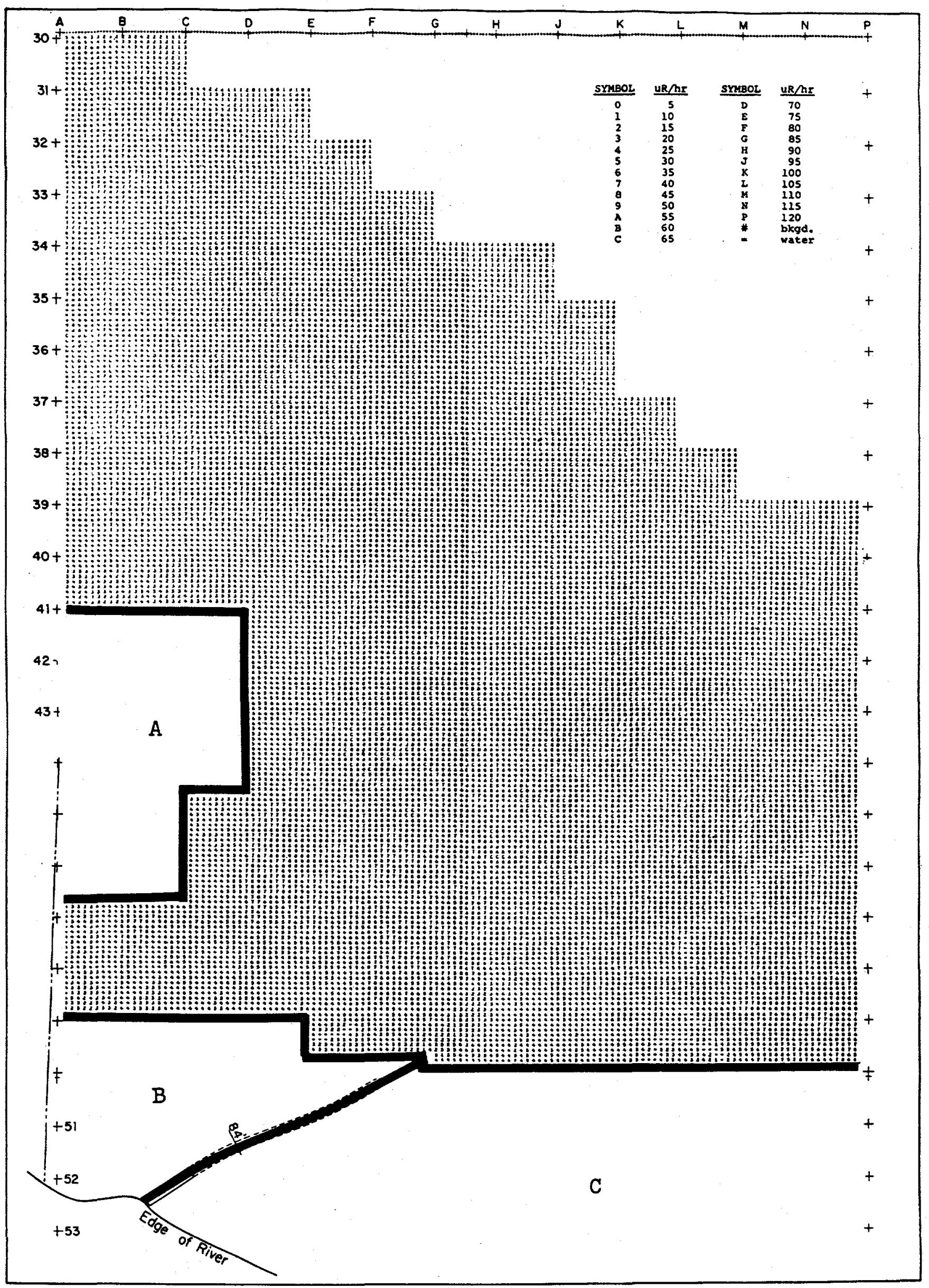

FIGURE 3. Grid Survey -0 to $120 \mu R / h r-5 \mu R / h r$ Increments 


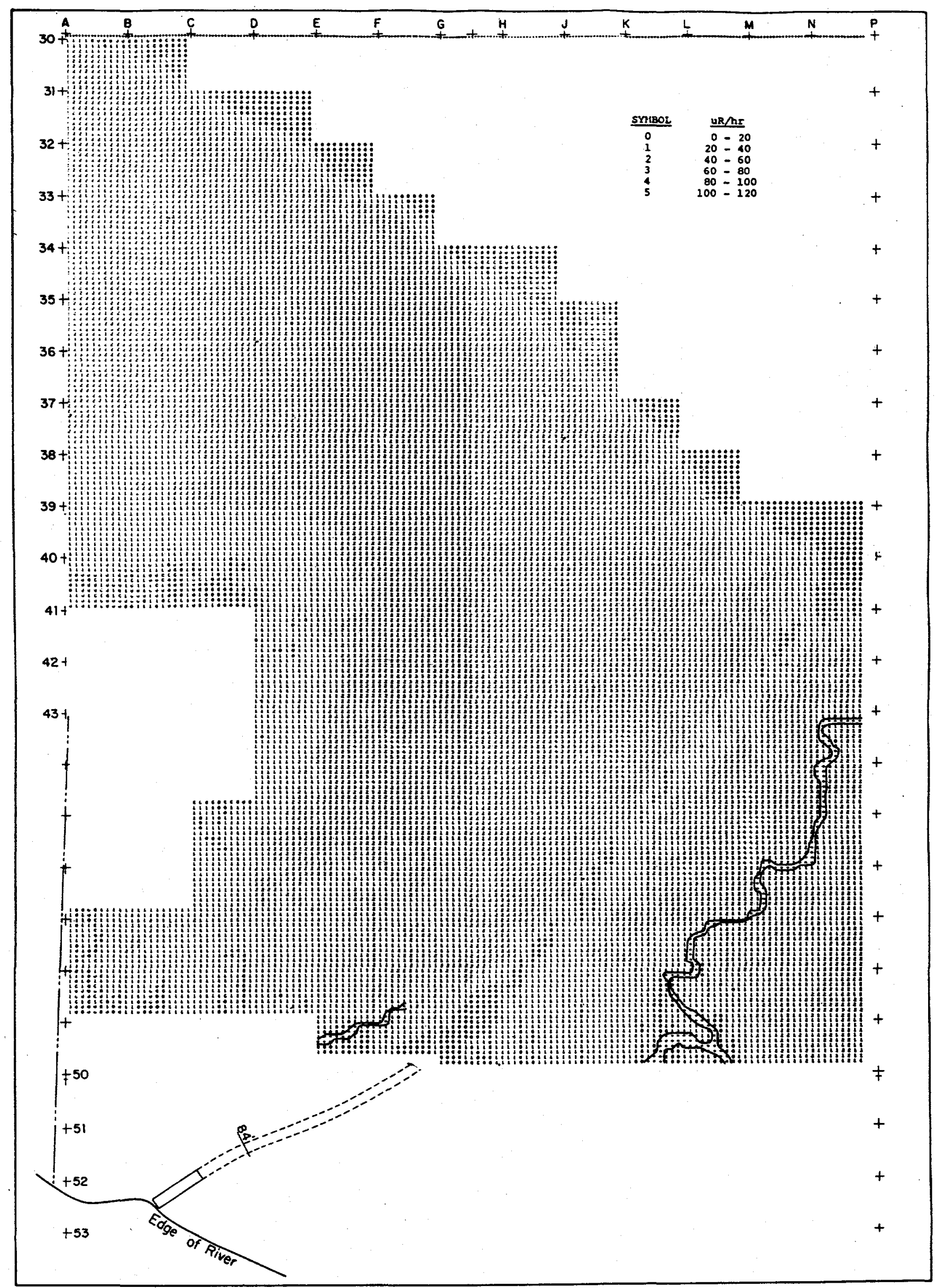

FIGURE 4. Grid Survey -0 to $120 \mu R / h r-20 \mu R / h r$ Increments 


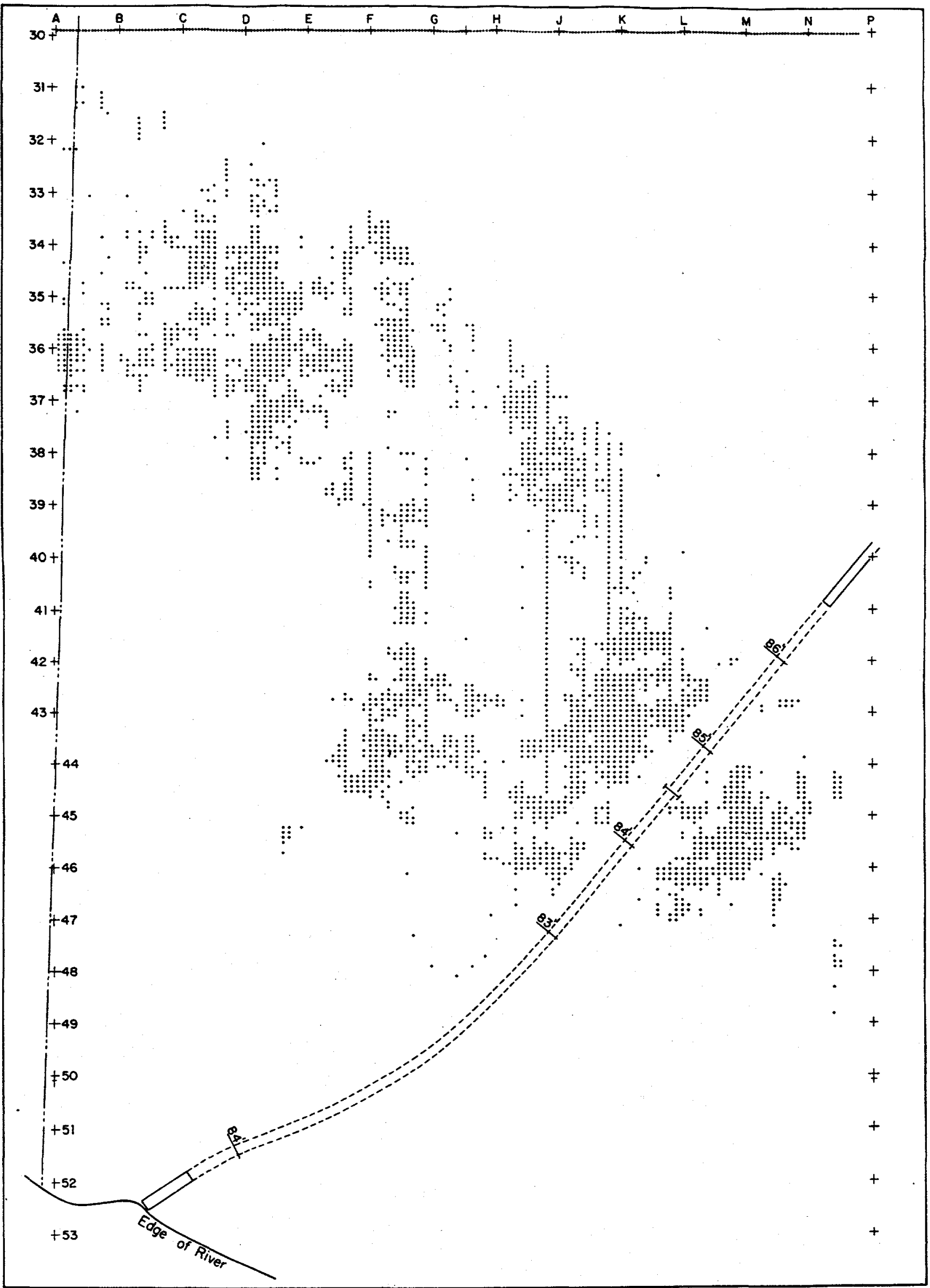

FIGURE 5. Exposure Rates Greater Than $57.1 \mu \mathrm{R} / \mathrm{hr}(\geq 500 \mathrm{mR} / \mathrm{yr})$ 


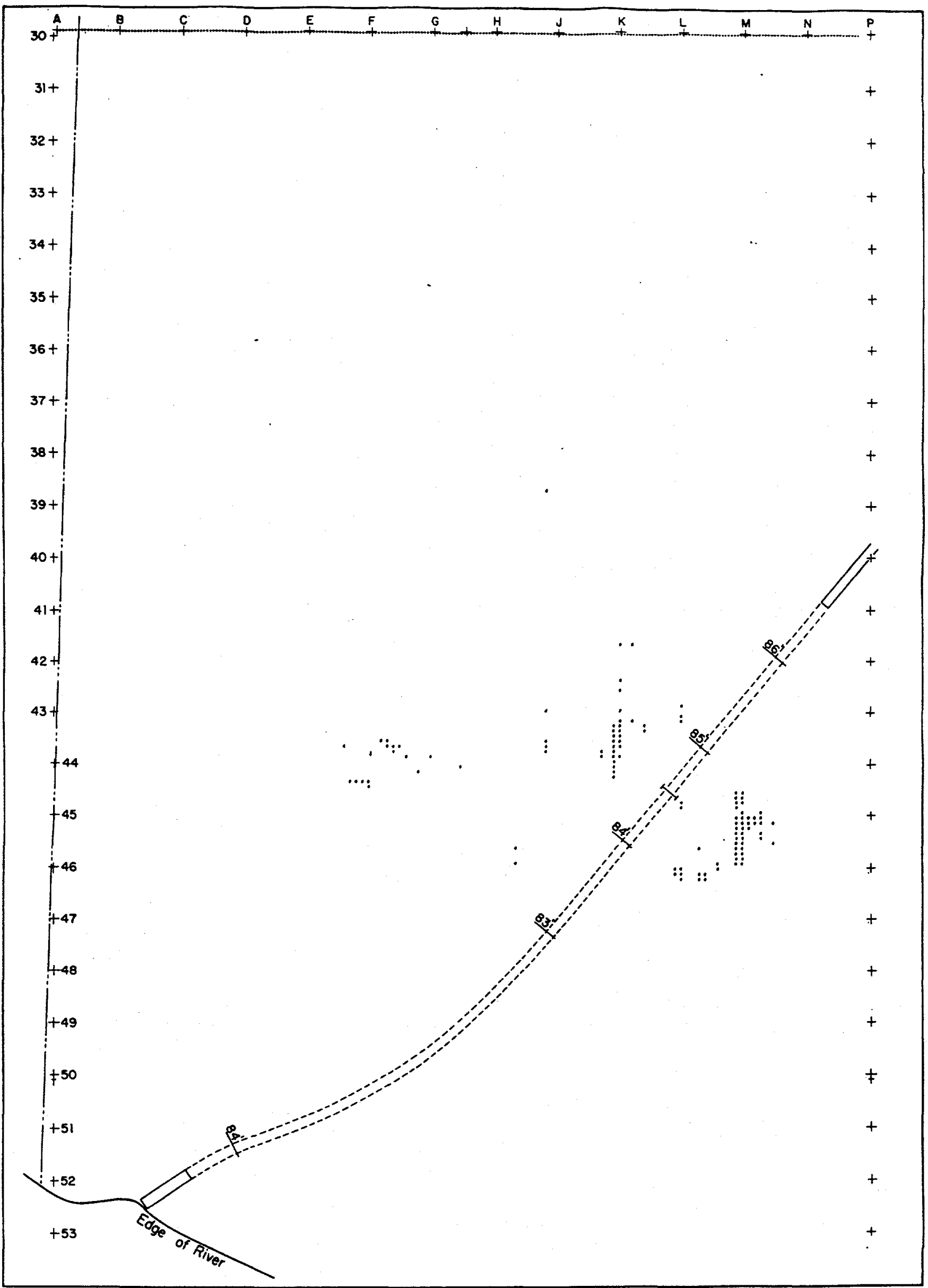

FIGURE 6. Exposure Rates Greater Than $74.1 \mu \mathrm{R} / \mathrm{hr}(\geq 500 \mathrm{mR} / \mathrm{yr}$ if occupied $77 \%$ of time) 


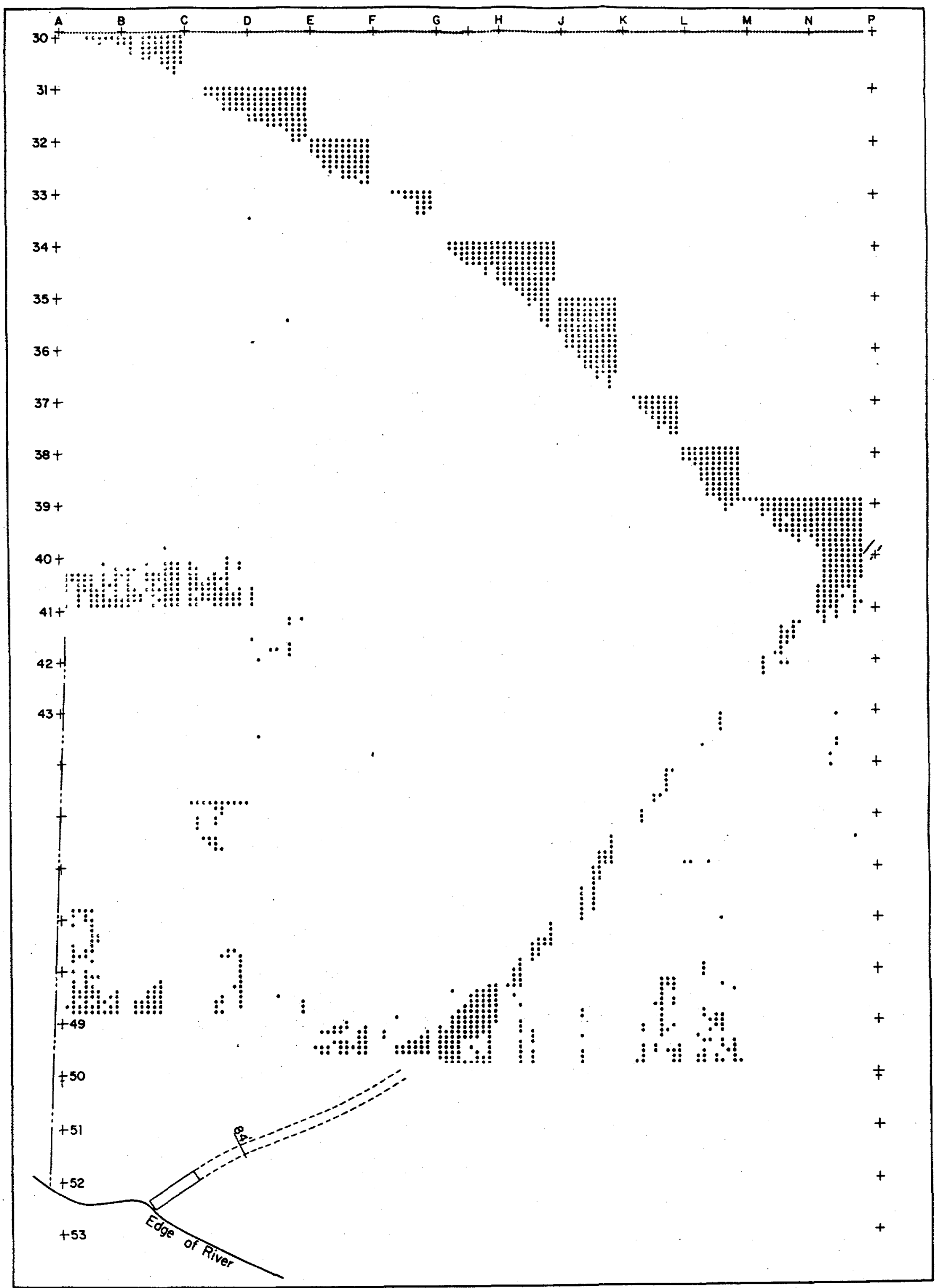

FIGURE 7. Exposure Rates - 0 to $20 \mu \mathrm{R} / \mathrm{hr}$ 


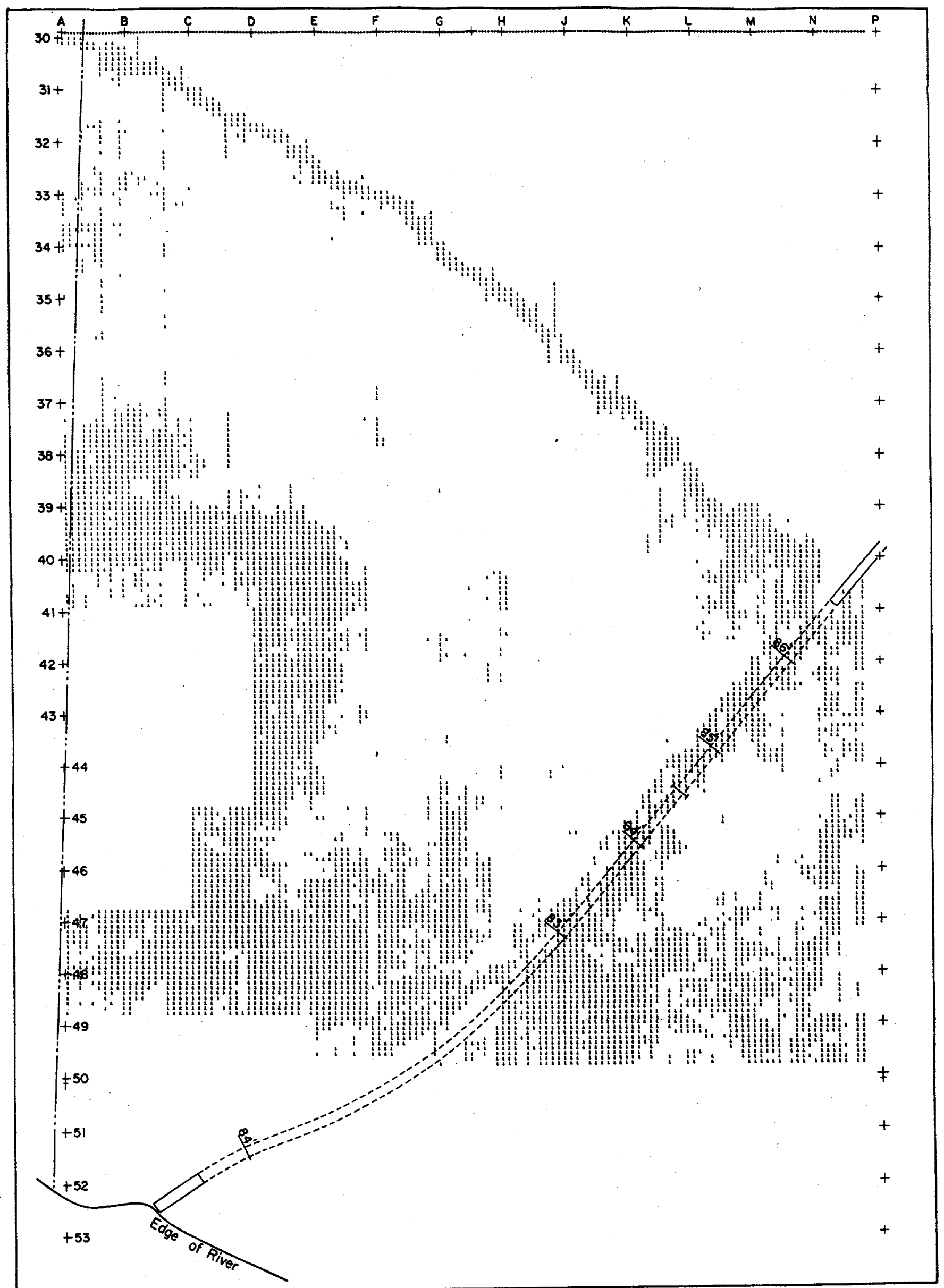

FIGURE 8. Exposure Rates -20 to $40 \mu R / h r$ 


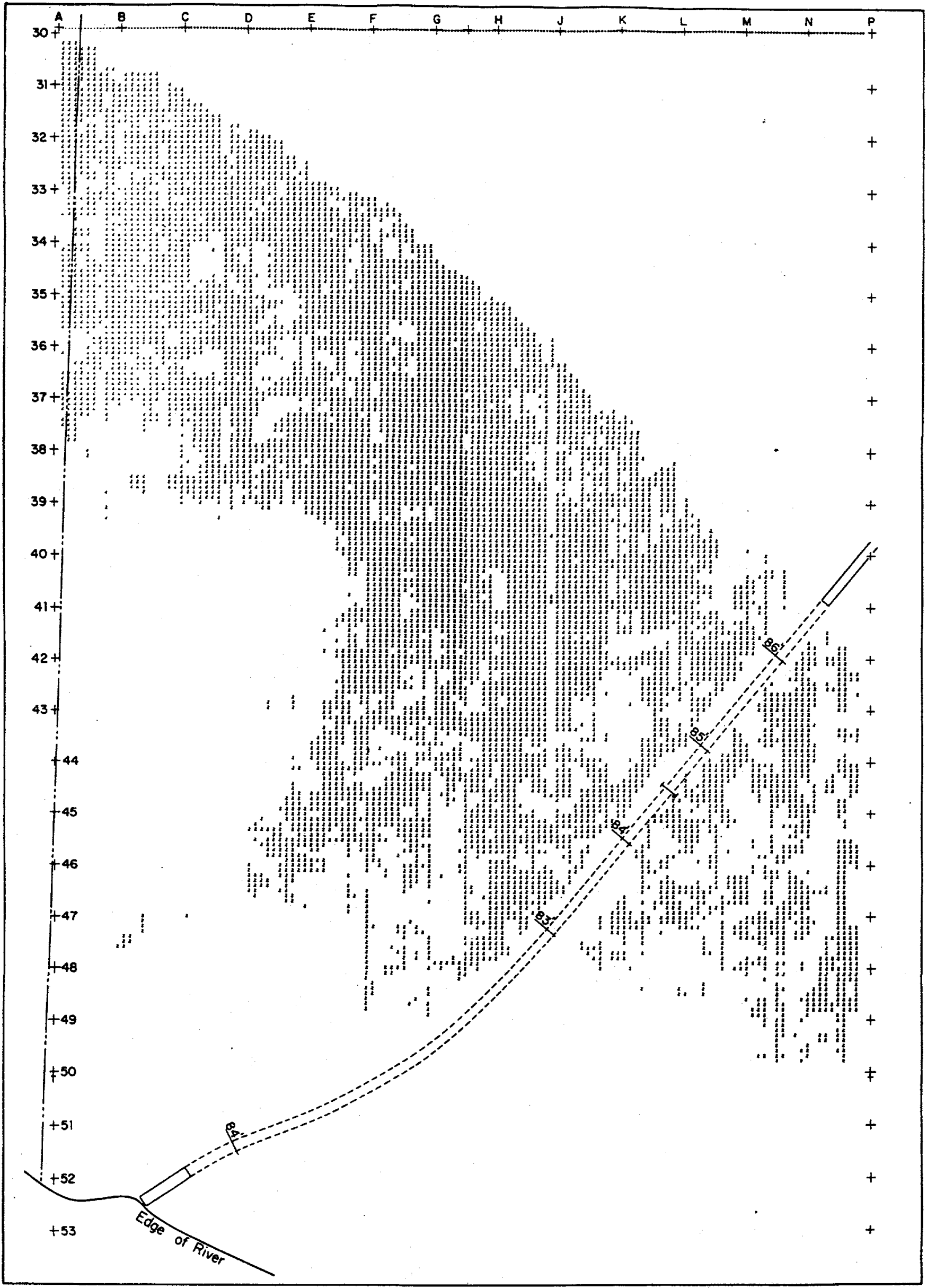

FIGURE 9. Exposure Rates -40 to $60 \mu \mathrm{R} / \mathrm{hr}$ 


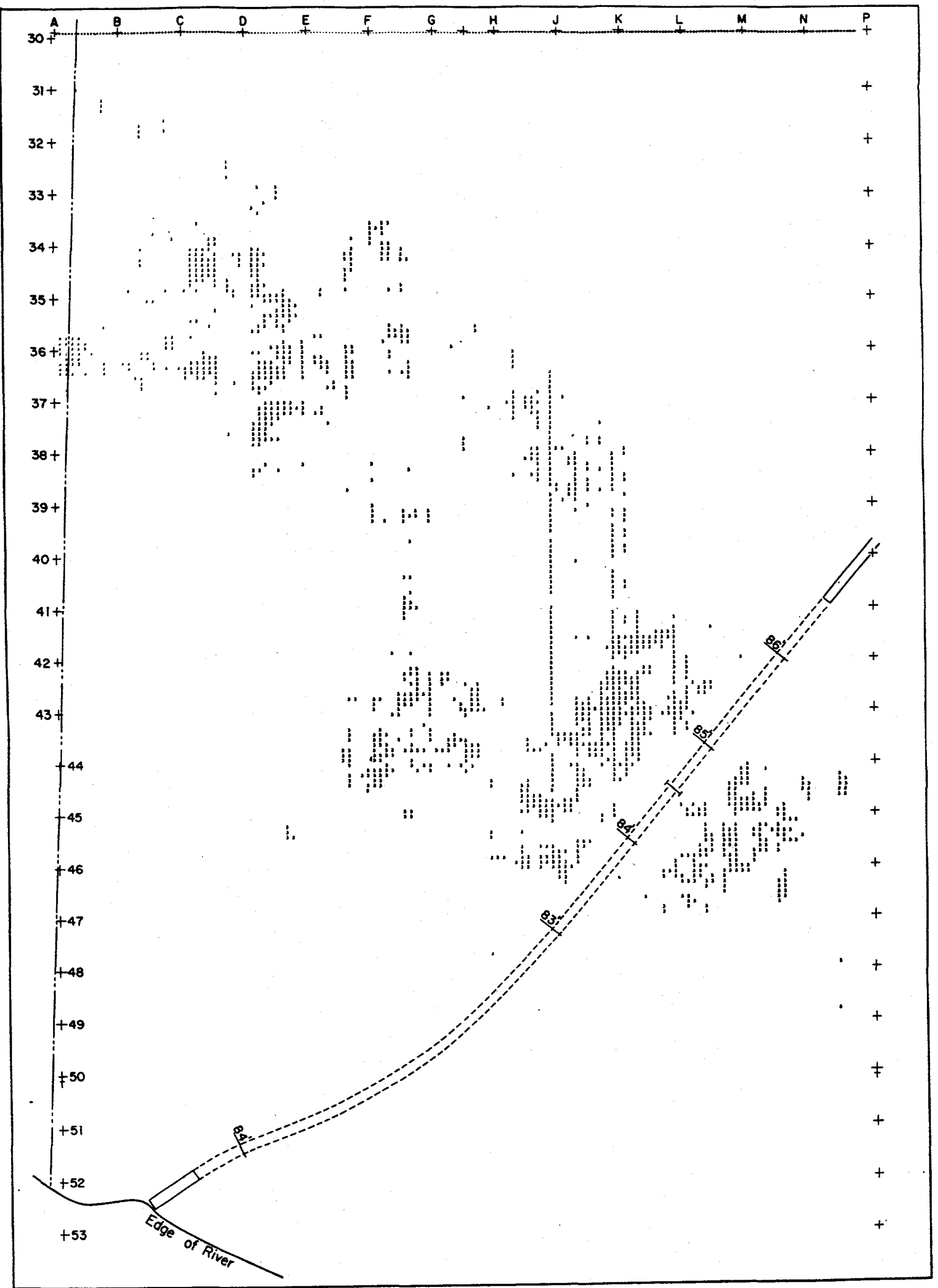

FIGURE 10. Exposure Rates -60 to $80 \mu \mathrm{R} / \mathrm{hr}$ 


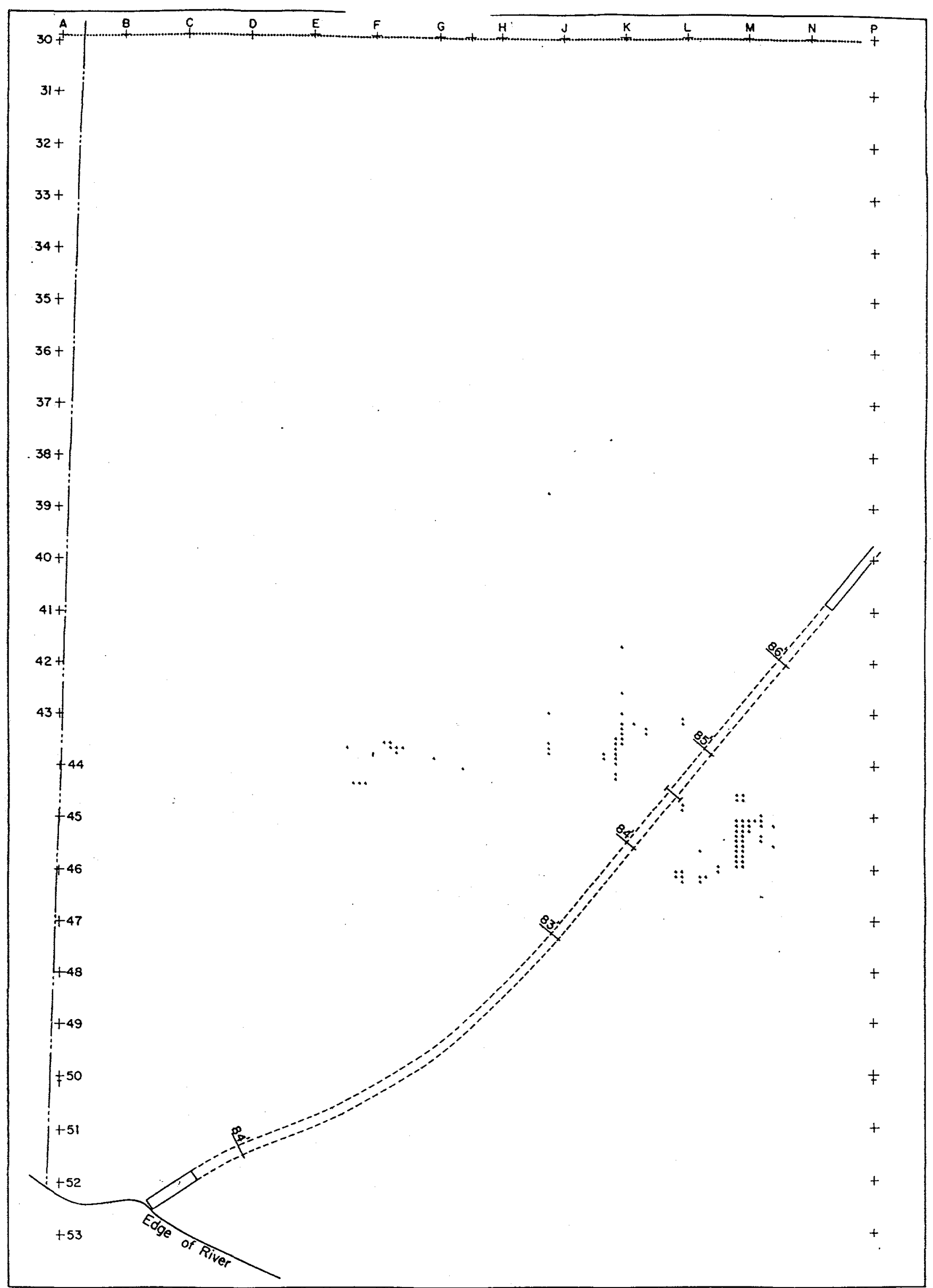

FIGURE 11. Exposure Rates -80 to $100 \mu R / h r$ 


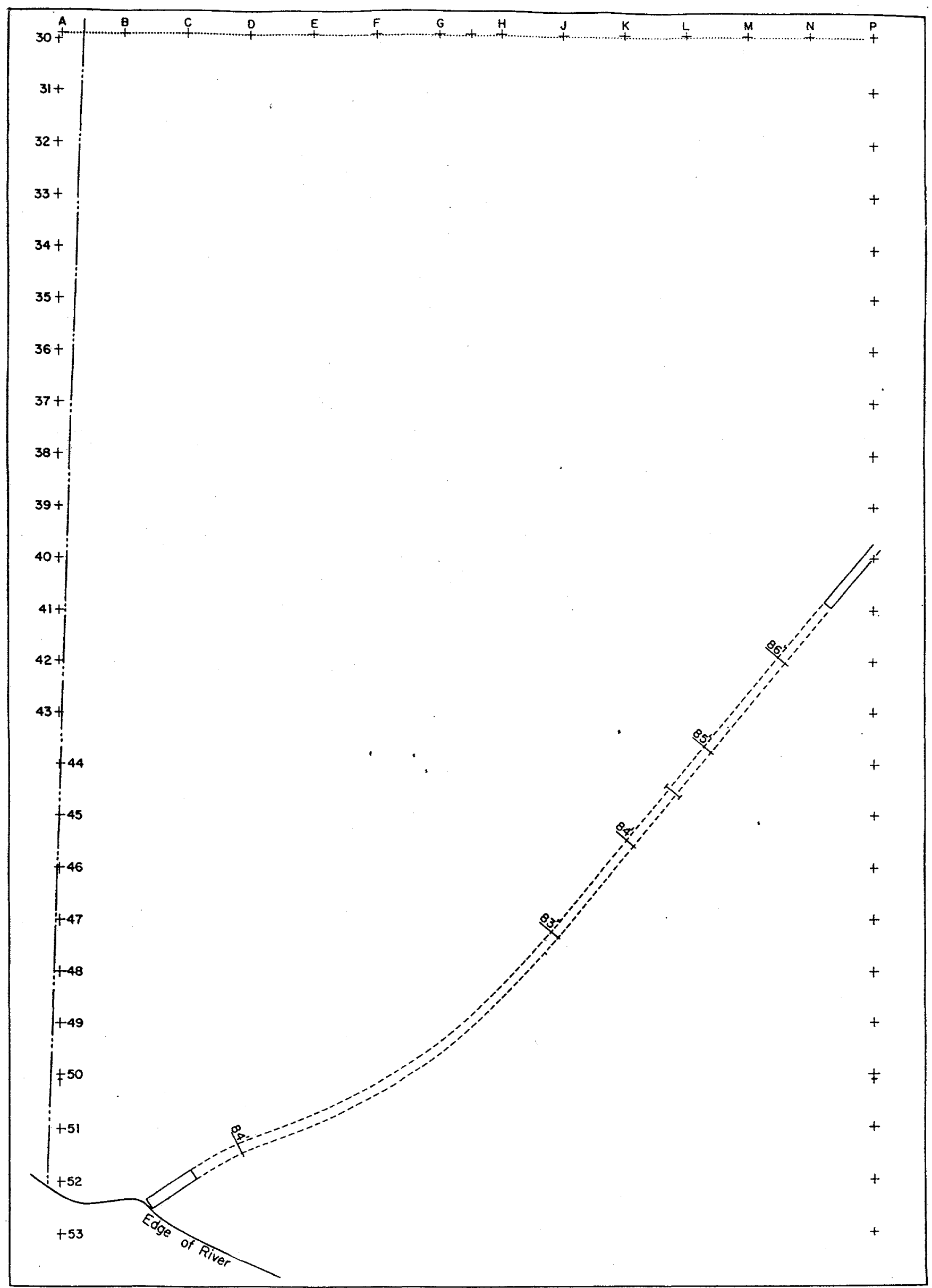

FIGURE 12. Exposure Rates - 100 to $120 \mu R / h r$ 